\title{
Bus drivers who leave; were they more crash-involved?
}

\author{
Anders E. af Wåhlberg* \\ A.E.Af-Wahlberg@cranfield.ac.uk \\ +44-1234 758225 \\ $\&$ \\ Lisa Dorn \\ 1.dorn@cranfield.ac.uk \\ +44-1234758229 \\ School of Aerospace, Transport and Manufacturing, \\ Cranfield University, Cranfield, Bedfordshire, MK43 0AL \\ UK \\ * corresponding author
}

\begin{abstract}
Acknowledgements
These data were made available to us by a major British bus operator, which is gratefully acknowledged. The data used in this papers have also been utilized in Dorn and af Wåhlberg (submitted, a; b) and af Wåhlberg and Dorn (submitted).
\end{abstract}

Disclosure statement: We state that we have no conflicts of interest or any financial interest in the application of this research.

\begin{abstract}
Turnover is usually considered to be a safety problem for companies, but can also be an advantage, if those who leave are less safe than those who stay. This problem has rarely been investigated for bus drivers, where the financial and human costs of crashes are high. This study tested whether bus drivers who left their jobs had more crashes than those who remained, using company records. Several analyses were run, using crashes per number of days worked, the absolute number of crashes in a specific time period, as well as the ratio of culpable to nonculpable crashes. Drivers who left the company, except those who retired, had forty percent more crashes than those who stayed, but were also less experienced, which explained part of the difference. Results were similar regardless of analysis performed. Turnover may be a problem for bus companies due to the costs of recruitment and training, but this study suggests that there are benefits for turnover too. Fleet-based companies would probably gain more by improving driver selection methods than trying to retain drivers with a high crash rate, as a natural selection process seems to lead to the safest drivers staying with the company.
\end{abstract}

Keywords: turnover; bus driver; accident; crash 


\section{Introduction}

\subsection{Personnel turnover, especially in bus companies}

Personnel turnover is usually viewed as something undesirable, by both managers and researchers, due to the high direct and indirect costs involved (e.g. Boxall, Macky \& Rasmussen, 2003; Faulk \& Hicks, 2015). Recruitment, training, loss of competence etc. are all costly to an organisation. However, some scholars have also pointed out that turnover is not only necessary, but might at times even be beneficiary (Hancock, Allen, Bosco, McDaniel \& Pierce, 2011; Harrison \& Gordon, 2014; Suzuki, 2007). This may happen when turnover is negatively associated with competence, i.e. the worst performers tend to leave, as found by McEvoy and Cascio (1987).

In some jobs, mistakes may be very costly. The human factor is usually responsible for the errors and the possibility of repeating the error is present. The nuclear industry is an example of this. Therefore, extreme measures of caution and multiple safety systems as barriers to errors are in operation. Another example, which is the focus of the present paper, is in transportation. The momentary decisions of the drivers represent the difference between safety and risk, and the skills with which they execute their driving task differ strongly between drivers. Here, it can be questioned whether there are savings associated with turnover, and if so, under what circumstances these might outweigh the costs?

In general, turnover in the bus industry is in the middle range (as compared to the metaanalytic data for all kinds of industries in McEvoy \& Cascio, 1987), with tens of percent of drivers leaving each year, often for medical reasons and/or stress (Tse, Flin \& Mearns, 2006). It can be noted that results for truck drivers indicate similar rates (Croon, Sluiter, Blonk, Broersen \& Frings-Dresen, 2004; Harrison \& Pierce, 2009), possibly with the US trucking industry as an exception, sometimes with reported rates of more than 100 percent (Corsi \& Fanara, 1988).

Due to turnover and shortage of drivers, it could be expected that bus companies try to retain as many drivers as possible. However, this might not be an optimal strategy (Suzuki, 2007), if the worst drivers tend to leave. This could be suspected to be the case for several reasons. Companies probably tend to dismiss individuals who have many crashes. Furthermore there might also be self-selection by drivers, who resign because they have been involved in a crash or crashes and feel uncomfortable with this kind of work, or anticipate being dismissed and therefore leave voluntarily.

The topic of whether professional drivers who leave their jobs are less safe than those who remain has rarely been studied. It was not included in the meta-analysis on turnover by Griffeth, Hom and Gaertner (2000), while the meta-analysis by Hancock, Allen, Bosco, McDaniel and Pierce (2013) did not analyse effects at the level of the individual. These omissions were probably due to a lack of available data, as it seems that very few studies are available. Häkkinen (1979) compared the crash records of bus drivers who left their jobs with those for drivers who remained with the company. Somewhat surprisingly, the drivers who left had fewer crashes. Two studies have reported that job change frequency and crashes are positively associated (Cantor, Corsi, Grimm \& Özpolat, 2010; Staplin \& Gish, 2005), using large samples of US drivers, and recorded data.

However, none of these studies took into account the methodological peculiarities of crashes, which will be discussed in the next section. Neither did any of them use any further categorization of reasons for leaving, such as voluntary or involuntary leave.

\subsection{Methodological considerations when studying crash involvement and turnover}

To be able to make precise calculations on future savings from crashes which can be avoided, several factors need to be taken into account. First, it can be noted that the whole undertaking of avoiding crashes by targeting highly crash-involved drivers (regardless of method) rests upon several assumptions about the relation between driver behaviour and crashes. 
First, differences between drivers in terms of numbers of crashes over time need to exist. Numerous papers have shown such an effect (see the reviews by Lester, 1991; Peck, 1993), and it becomes more pronounced with time, as the number of drivers with no crashes decrease (Dorn \& af Wåhlberg, 2008).

Second, there must be stability in crash involvement, i.e. future crash involvement is predicted by previous involvement. This feature of crash involvement has been denied by safety researchers for decades, but has recently been shown to exist and to be a very strong factor (Visser, Pijl, Stolk, Neeleman \& Rosmalen, 2007; af Wåhlberg, 2009a; af Wåhlberg \& Dorn, 2009a). The apparent instability of crash record is due to low variance when short time periods are studied (af Wåhlberg, 2009a).

Third, this stability over time is only a feature of the crashes which the drivers have caused, while non-culpable crashes are random occurrences which are only related to exposure (af Wåhlberg, 2009a). This means that if all crashes are used as dependent variable, the nonculpable ones will act as a confounding variable. This reduces the effect by some 10-20 percent; (af Wåhlberg, 2018). What fleet-based companies deem to be at-fault crashes is usually based upon the legality of the behaviour of the driver, not whether the behaviour was the cause (Dorn \& af Wåhlberg, submitted, a; af Wåhlberg, 2009a; af Wåhlberg \& Dorn, 2007).

The fourth problem in individual differences in crashes research is that of exposure. If comparisons of numbers of crashes between drivers are to be valid, they should be exposed to similar dangers, both in terms of quality and quantity. Unfortunately, this problem has not been thoroughly researched in terms of individual differences (af Wåhlberg, 2009a; 2011). For bus drivers, their number of hours worked should be held constant (although calculating crashes per exposure tends to yield strong outliers, due to the combination of a crash and a short time of employment). If this data is not available, only full-time drivers should be used in calculations. However, as crashes and absence tend to be positively correlated (af Wåhlberg \& Dorn, 2009b), this method will probably under-estimate the number of crashes per hour for the high-risk drivers. A possible method which should counter this problem is to use nonculpable crashes as a measure of exposure. This is similar to case-control methodology, and goes by the name of induced exposure in traffic safety research (e.g. Carr, 1969; Chandraratna \& Stamatiadis, 2009; Cuthbert, 1994). Induced exposure should in theory control for both quantity and quality of exposure. However, controlling for quality of risk (i.e. differences in risk between different routes, times of day etc) may not be necessary. Häkkinen (1958) calculated the differences in risk between routes and found them to be negligible, while Jovanis, Schofer, Prevedouros and Tsunokawa (1991) reported that the strongest predictor of differences between routes was the distance of the route, i.e. the amount of exposure for a driver is more important than other factors. For drivers working eight hour days, the differences between levels of risk at different times of day should be small (af Wåhlberg, 2009b).

A final methodological problem in crash/turnover research, related to that of exposure, is the experience (total amount of exposure) of drivers, which is usually heavily confounded with age-related changes. Therefore, when calculating whether certain drivers should be retained within a company, it must be taken into account that the crash risk of bus drivers is reduced by about fifty percent in the first one or two years of driving, and continues to shrink up until about ten years of employment (Dorn \& af Wåhlberg, 2008; af Wåhlberg, 2005). Age, on the other hand, is a rather weak factor (Blom, Pokorny \& van Leeuwen, 1987; Cornwall, 1962; Dorn \& af Wåhlberg, 2008), probably due to the fact that most drivers retire before any agerelated changes make them more risky. 


\subsection{Summary and goals}

The present paper will present data regarding bus crashes and turnover, and calculate the differences between leavers and stayers, thereby testing which group has the higher risk. Also, further sub-groupings according to reasons for leaving will be tested for possible differences in crash rates. From the perspective of individual differences in traffic safety, the results can be seen as further evidence regarding what kind of factors are associated with crash involvement.

Therefore, the present study set out to compare the crash records of some different groups of professional drivers, based upon the reasons for leaving their jobs, and the bus drivers that remained with the company. To control for methodological problems, several different computational approaches were used. It was predicted that in general, effects would be slightly stronger for at fault crashes as compared to all crashes.

In summary, the present study adds to our knowledge concerning the association between turnover and safety where little is known about this. Furthermore, the calculations are more refined than any previous ones. This study uses categories of crashes and the reasons why drivers left recorded in a large set of data.

\section{Method}

\subsection{General}

Data was made available by a major bus company operating in the UK, for the time period 2006-2008 ${ }^{1}$. This included number of at fault and no fault crashes (collisions with other objects), as judged by company officials, for more than 5000 drivers (further described in section 2.2 .

The bus company taking part is a UK-based international passenger transport group and the UK's largest bus operator running more than $20 \%$ of all local bus services. With a fleet of nearly 9,000 buses at the time of the study, it carries some 1.6 million passengers a day in more than 40 major towns and cities. The bus company operates alongside other local and national bus companies in the same towns and cities. It is therefore expected that exposure is similar and that the present results may be comparable to those of other bus companies. As the company operates in other countries, similar operational systems can be expected to be in place as those for the UK.

\subsection{Sample characteristics and driver categories}

To become a UK bus driver a full car driving licence is required plus a professional driving qualification called the Driver Certificate of Professional Competence (CPC). The Driver CPC includes a theory test covering knowledge of the road rules and driving ability. Bus drivers must also undertake 35 hours of periodic training every 5 years to stay qualified to drive a bus.

On local services bus drivers can expect to drive for a maximum of 10 hours a day. On longer trips, drivers will drive for a maximum of 9 hours a day, up to 56 hours in a week, or up to 90 hours over 2 weeks. Bus driving may be scheduled beyond the guaranteed 38 hour week with 'spread over' duties (split shifts). Bus companies typically have shifts starting at various times of the day or night to divide the workday into separate parts. A split shift may involve up to an 8 hour unpaid break in between shifts. Whilst it is not known what percentage of our sample were on split shifts, based on the bus industry as a whole this can be expected to be a significant proportion.

\footnotetext{
${ }^{1}$ This data was made available as part of an evaluation project in 2009. Although time did not permitt us to analyse these data in full at the time, we believe the data to be valid for driving in later decades too. In fact, in a meta-analytic accident dataset spanning seven decades, we have found no differences in effects over time (af Wåhlberg, 2009).
} 
The original dataset contained a list of 12892 drivers. Of these, 284 were part time drivers, and 50 had an unknown status, and were deleted. Furthermore, 7292 drivers had left their employment before 01-01-2006 (when the crash data started) and could therefore not be included. Crash data was made available in a separate file and merged with the driver list. After cleaning the dataset for double entries and missing data, 5060 drivers were left who could be included in the sample for the current study.

Data on these drivers was available for crashes, gender, date of birth, dates of employment (start/end) and reasons for ending of employment in seven categories (see Table 1). Of these categories, the 'Transfer' group was defined as going to work for another firm within the same group, probably due to moving house, while the 'Other' category was a miscellaneous group which might contain people with health problems. The 'Retirement' category contained some people who were obviously too young to retire according to their age, which probably means they had health problems. 'Resignation' and 'Dismissal' may be very different variables, but in practice, this would not necessarily be the case, as an agreement could be reached by the company and driver that he/she was unsuited for the job, and had better resign voluntarily instead of being dismissed. Thus, the labels attached to different cases of turnover may not always be exactly what they look like in these data, and should be treated with caution. Part time drivers were excluded from this dataset, as they may not be comparable to full time drivers, if nothing else than because of their lower exposure, but also because their reasons for working as drivers and leaving might be different ${ }^{2}$. Data for crashes and employment were in different files, but could be matched by employment number.

\section{Table 1 about here}

\subsection{Methodological considerations for crashes}

As described in the introduction, crash data need to be controlled for the confounders of differences in exposure, culpability and experience. In the present paper, these problems were handled in several different ways, with parallel calculations.

First, only full time drivers were used. Although this should, in principle, equate their quantity of exposure, there still remained the problem of different risks in different areas, and absence from work, of which no information was available. To control for these possible differences, induced exposure was used, i.e. the ratio between culpable and non-culpable crashes (Haight, 1973).

The crash data in the present study was coded for fault of the driver as categorised according to the bus company. In principle, the no-fault category should therefore be an index of exposure, which could be used to test whether drivers differed on this variable. This method, however, rests upon the assumption that the coding of crashes is correct. In the present data, it can be suspected that the coding by the company mainly reflect insurance requirements, and not whether the drivers have actually been involved in causing the crashes (Dorn \& af Wåhlberg, submitted, a; af Wåhlberg \& Dorn, 2007). The no-fault crash variable in this data should therefore be seen as a very rough approximation of quantity of exposure. However, there is no reason to believe that this will cause any systematic differences between the groups studied. The at-fault variable in the present data, on the other hand, should be eminently suited for testing whether the company tended to dismiss drivers who had cost them money by being legally at-fault in their crashes. Therefore, separate calculations were made for this variable.

\footnotetext{
${ }^{2}$ Calculations on the original group of almost 13000 drivers indicated that part time drivers were strongly overrepresented in the Retirement group (seven times their percent in the population), despite only being on average 1.4 years older than full time drivers. This, and a slight over-representation in the Death group might indicate that drivers with health problems were given part time employment.
} 
Finally, experience was controlled for by comparing the crash rates of sub-groups of leavers and stayers who had been hired at the same time.

\subsection{Statistical analysis and methodology}

There are many different statistical tests and measures of association available which highlight slightly different aspects of the effects in the data (but most of these can be converted into each other; Field \& Gillett, 2010). Several parallel analyses should therefore always be run and reported (af Wåhlberg, 2010). This yields a more comprehensive picture of the results and saves the reader the work of converting effects.

The effects in the present study were first presented in terms of independent t-tests, which yield a measure of significance, a rough measure of the precision of the results. The t-value, however, is to some degree based upon the degrees of freedom, and is thus not a pure effect size measure. Therefore, Cohen's d was also used (an effect size metric which is almost independent of degrees of freedom, and expresses the differences between means in terms of standard deviation units), and in some instances percent.

Finally, to control for possible moderating variables (i.e. age, gender, and experience), a multivariate analysis was conducted. The choice of statistical method for this analysis, however, is difficult. A Poisson regression model should not be used, because the variance is greater than the mean. Similarly, crashes are not Poisson-distributed for individual drivers, unless the time period canvassed is very short. The Negative Binomial regression model has become increasingly popular in modelling of crash data for individuals. Here, it will be argued, however, that this may be problematic, as number of crashes per individual does not have the same statistical properties as number of crashes for a road or junction. The latter is a situation for which this method is usually used (e.g. Coruh, Bilgic \& Tortum, 2015). The negative binomial model assumes that count data is used. In the present study, however, some dependent variables are continuous variables (crash/exposure). Also, count data are assumed to result from a series of Bernoulli trials (where there are only two outcomes). This appears to be a poor description of the continuous experience and behaviour of drivers over time. Both of these assumptions would seem to be true for road traffic engineering, but importing them into individual differences is erroneous.

For these reasons, it was decided to use multiple regression, which can handle continuous dependent variables as well as dichotomous predictors. In this analysis, age, gender and experience was used as predictors of crash involvement along with reason for leaving in a dichotomized form (stay/leave), as described further in the results section.

Three different methods were used to control for differences in exposure. First, crashes in the period 2006-2008 were divided by the number of days each driver had been employed ${ }^{3}$ during this time, as this differed very strongly, due to some drivers leaving. However, this method easily creates outliers and large standard deviations. Therefore, a second analysis was run, where drivers who had worked during the whole year of 2006 were compared for their absolute number of crashes during this year. Finally, ratios between at-fault and not at-fault crashes were computed.

Culpability for crashes was handled by calculating parallel analyses for all crashes and at-fault only. In theory, the latter is the important one, but to make results comparable to other studies, the 'all crashes' variable was also used.

Table 2 about here

\section{Results}

\footnotetext{
${ }^{3}$ Although all drivers in the sample used worked full time, this variable is not exactly the same as time worked, due to possible absence.
} 
In Table 1 can be seen descriptive results for the different groups of drivers on experience, time worked during the period of 2006-2008, and age. Drivers who retired were much older and more experienced than the others, which was also to some degree true for those who died. Of some interest was the fact that drivers who resigned did so after rather a short time period, as compared to the other groups.

The means for crash rate for the period 2006-2008, are shown in Table 2, and the differences between them expressed in two different effect size measures in Table 3. For the category 'Other', one case was excluded from the at-fault and all crashes/kday variables, due to being an extreme outlier (333). Distributions for the crash variables can be seen in Figures 1-2. Looking at Table 3, it can be seen that drivers who were still with the company at the end of the period had the lowest crash rate of all drivers, followed by those retiring. These two groups also had the lowest percentages of at fault crashes. The highest crash rate was found for the drivers who voluntarily resigned from the company, not those who were dismissed. The category 'Other' also had a very high crash rate. However, as we do not know what this category actually contains, it is impossible to interpret apart from it being in line with the general result that drivers who leave the company are highly crash-loaded (except for those who retire).

The ratios at-fault/not at fault were fairly similar for the two different calculation periods, with two exceptions; Other and Death. Especially for those who died, a very large change for the worse seems to have happened after 2006, but as this group was also very small, this result may not be reliable.

Table 3 about here

Figures 1-2 about here

The values in Table 2 were thereafter analysed for effects between groups, given in terms of $t$ tests and Cohen's d (shown in Tables 3-4). The significance of the t-values mainly indicates the reliability of the effect, while $d$ is a better estimate of the size of this effect. The results in these two tables tend to confirm the conclusion from Table 2, that the drivers who remain and those who retire are different from those who leave, as it is mainly between these two and the rest that significant, but not large, effects occur (mean $d$ for comparisons of stayers and leavers; 0.25 for at fault and 0.21 for all crashes). For the retirement group, the effect sizes in Table 3 were smaller than those of the stayers ( 0.15 for at fault, 0.09 for all crashes), and not significant at $\mathrm{p}<.05$, as that category was much smaller than some of the other groups.

Thereafter, the leavers, not including retiring drivers, were collapsed into one group, and the calculations of Tables 3-4 re-run (see Table 5). As can be seen, the leavers and stayers did differ in experience by about two years. To achieve an estimate of how much this influenced the results, the difference in crashes in 2006 was calculated between sub-groups that were equal in experience (last two rows in Table 5). As these group were rather small, the differences were only significant at $p<.10$. The $d$ and percent values, however, were similar to those of the middle two rows, and indicated that less than a quarter of the effects in the tables can be attributed to differences in experience.

Tables 4-5 about here

Thereafter, a series of multiple regressions were run, with all and at fault crashes per work day for the whole time period as well raw numbers in 2006 as dependent variables. Predictors were age, gender, experience and leave reason. Given the results of the bi-variate analyses, retiring drivers were excluded, and all other leave categories collapsed into one. The leave parameter was thus dichotomous, comparing all leavers (except retirees) with those who 
stayed on. The results can be seen in Table 6 . The results showed that leave/stay was rather consistently associated with crash involvement across the different dependent variables, while age had quite a different effect for the at fault 2006 variable. Separate models were run with dichotomisations between stayers and the leave categories Dismissal and Resignation as predictors. The beta coefficients for leave/stay remained remarkably similar across these alternative analyses (not shown).

Also, due to the difficult distribution of the crah variables, logistic regressions were run with all and at fault crashes 2006-2008 as dependents and age, experience, gender and leave status as predictors, holding the number of days worked constant. The results (Table 7) were very similar to those of the multiple regressions.

Finally, a comparison of crashes between drivers leaving and drivers hired in the same year (but excluding those who were both hired and left within that time period) was undertaken (see Table 8). It can be seen that in 2006-2007 new drivers had more crashes than leavers, but in 2008, the direction of the effect changed. Overall, there was therefore virtually no difference between these two groups. Although the crashes/kday variables contained some outlying values for leavers in 2008, this does not explain their very high values, as their absolute numbers were also higher. This was in spite of them working slightly fewer hours than the new drivers.

Finally, at fault crashes in general had slightly higher effect sizes than all crashes (1.9 percent in Table 3, -3.2 percent in Table 4, 7.0 percent in Table 5 and 5.4 percent in Table 8).

Tables 6-8 about here

\section{Discussion}

\subsection{Results}

The overall result of the present paper is that bus drivers who leave their job tend to differ in terms of safety compared with those who stay, with the exception of those that retire. Most interestingly, it is the drivers who resign who have the highest crash frequency, which is even higher than for those who are dismissed. These results are in agreement with the results of the analyses of McEvoy and Cascio (1987), Cantor, Corsi, Grimm and Özpolat (2010) and Staplin and Gish (2005).

However, these results are very different from those of Häkkinen (1979). First of all, only about a third of the bus drivers in his study left their occupation over a period of more than ten years, suggesting remarkable stability within the workforce. Furthermore, the resigned group had fifty percent fewer crashes than those who remained, but were on average only three years older.

The bus drivers in the present data had fewer years of experience (indicating high turnover) as compared to Swedish bus drivers (less than half, af Wåhlberg, 2005) and especially those in Häkkinen's study, but similar to the Dutch drivers in Blom, Pokorny and Van Leeuwen (1987) and the British drivers in Dorn and af Wåhlberg (2008). In the present study, there was a negative association between tenure and resignation, as those who left voluntarily had two to three years lower tenure compared with those who stayed. This result is in agreement with the general literature on turnover (Griffeth, Hom \& Gaertner, 2000; Mobley, Griffeth, Hand \& Meglino, 1979). As for the drivers categorised as 'Other' the reasons for leaving differences were not so large, with those retiring and those dying actually having longer tenure than those still working at the end of the period. Across the categories, there were thus slightly different patterns for tenure and crashes.

Some peculiarities can be noted; drivers who were promoted also had a very high crash rate. Apparently, you do not get promoted because you are a good driver. One possibility is that 
high risk drivers are promoted to supervisors to remove them from the driving task and reduce the company's liability. Also, drivers who retired did not have a lower crash rate as compared to those remaining, despite a much higher level of experience. This result is especially strange as a parallel analysis on experience and age has indicated that the former has a fairly linear effect, while the latter has no measureable impact (af Wåhlberg \& Dorn, submitted). The effects found in the present study would seem to indicate that road traffic crash involvement is an indicator of the probability that a driver leaves the company, which is similar in strength to many other indicators (i.e. small, or possibly moderate), such as job content, stress, pay and job satisfaction (Griffeth, Hom \& Gaertner, 2000). It is of course likely that crash involvement is intertwined with these factors, maybe especially stress, and it cannot be said whether a simple causal mechanism exist in either direction.

The size of the effects in the current paper were mostly small, with a few medium effects, according to the standard of Cohen (1988). However, as noted in the introduction, this is common for accident prediction studies (af Wåhlberg, Barraclough \& Freeman, 2016). If an average difference of $d=0.25$ is accepted for the current results, this is the same as a Pearson $r$ of about .108. Although exact comparisons are difficult to make due to statistical and computational differences between studies, this means that the effect for leavers/stayers is probably larger than that for personality (af Wåhlberg, Barraclough \& Freeman, 2016), ADHD (Vaa, 2014) complex reaction time and level of distress (Arthur, Barrett \& Alexander, 1991), but smaller than those for previous accidents (af Wåhlberg, 2009) and traffic offences (Barraclough, af Wåhlberg, Freeman, Watson \& Watson, 2016).

\subsection{Limitations}

The main problems in the present data were the rather small numbers of drivers in some categories, and the company-coded fault variables. The low number of participants can create unreliable effects, and the results for retirement, transfer, death and promotion should therefore be treated with caution. However, all effects would seem to point to the conclusion that drivers who remain with the company are safer than those who do not, with the exception of those who retire.

Future research into the safety of leavers and stayers in fleet-based companies need to overcome the problem of outliers in the data. Holding exposure constant by using the same time periods for all drivers would seem to be a good solution for this, but requires database setups which are somewhat complicated. The best method would seem to match each leaver with a stayer, for the time period of the leaver's employment.

The coding of responsibility for crashes was undertaken by the bus company, in ways that might not be uniform, and were not known to the authors. Investigations of this coding has indicated that crashes designated as no-fault by the bus driver are not a good measure of exposure (Dorn \& af Wåhlberg, submitted, b). It was therefore assumed that these crashes were mainly a reflection of costs for the bus company. Although the results of analyses using no fault crashes as an index for costs (the ratio of fault to no fault) were in agreement with the other findings, indicating higher safety for drivers who stayed and for those retiring, the exact meaning of the no-fault category of crashes cannot be reliably established in these data. In a parallel study on these data (af Wåhlberg \& Dorn, submitted) it was found that there was a reduction in crash rate over the years covered (2006-2008), probably due to a general trend in reduction in road traffic incidents, which in its turn was probably due to the financial recession at this time. This effect would tend to increase the difference between drivers who were still with the company at the end of the period, as compared with those who left earlier. However, the crash reduction effect between full years only explained less than a fifth of the effect of experience in these data, and there is no reason to believe the presently reported effects should be more affected than observed. On the contrary, the group of drivers who were still with the company must contain a fair percentage of drivers would be expected to leave 
within months or years, due to a high crash rate. Thus, if anything, the present results are probably an underestimation of the resignation effect.

It can be seen from the means on crash rates (crash/kday) that the differences between driver groups are rather large, in terms of percent, while the effect sizes reported are small to moderate. This is to some degree due to the problem of variance in the data when the absolute number of crashes in a period is divided by the exposure term. This mathematical operation tends to create outlying values from the combination of low exposure and one or more crashes) and in general rather high standard deviation values (especially for the variable 'Other' in the present data), which decreases the effect sizes.

Another problem with the crash data is that there is no information about the severity of the crashes. Although the original data file contained information about the cost for each crash, this variable does not only reflect the severity of the crash, but also the legal circumstances (at fault crashes had costs that were on average almost four times as high as those of non fault crashes). Therefore, it was not possible to take this factor into account. It is acknowledged that drivers might be more liable to quit after a severe crash, but this cannot be ascertained in the present data.

\subsection{Conclusions}

Why are bus drivers who leave their employment more crash-involved than others? There are several possible explanations for this, although little evidence concerning any of these can be forwarded. First, leaving may not be fully voluntary, but the result of conflict with managers and supervisors perhaps due to the drivers' crash rates (see Probst \& Brubaker, 2001, for a result of this type). Second, drivers may find repeated crash involvement to be an unpleasant experience and affect their willingness to be a driver, although this would seem to be an unlikely explanation, as drivers do not appear to change their driving behaviour due to crashes (af Wåhlberg, 2012a; but see also Rajalin \& Summala, 1997). However, drivers with less capability for professional driving may find their work more stressful and tiring, and have more crashes, i.e. leaving the company is not caused by crash involvement, but both this and leaving the company are caused by a third variable. Yet another possible third variable is ill health, as crash involvement is also associated with absence from work (af Wåhlberg \& Dorn, 2009b), and bus drivers are notorious for their bad health (Evans, 1994; Taylor \& Dorn, 2006; Tse, Flin \& Mearns, 2006). In conclusion, it can be said that there are currently no psychological tests with high enough validity to use in selection of drivers. Improvement of tests and/or development of new testing methods is therefore necessary.

However, it should be pointed out that regardless of the reasons for leaving a company, crash involvement is highly predictive of future incidents (af Wåhlberg, 2009a). Therefore, even if turnover is caused by being involved in a (culpable) crash, this does not mean that the present results are invalid in any way. Instead, the point is that drivers who have crashed should be encouraged to leave, as they are likely to crash again.

The present results could to some degree explain the recently reported meta-analytic result of virtually no (linear) association between turnover rate and organizational performance (Hancock, Allen, Bosco, McDaniel \& Pierce, 2013). Within turnover research, different models have been suggested for this association, using assumptions about the costs of hiring and training new employees versus the advantage of avoiding skill stagnation. The present results on the other hand indicate how transportation companies can save money directly by allowing for turnover, as crashes that may have happened can be expected to be avoided, because the crash rate for the resignation group was about ten percent higher than for the population of drivers in their first three years of employment in these data (af Wåhlberg \& Dorn, submitted). If the present results are representative for companies in general where safety is an issue, it may be that voluntary turnover may at times actually be saving the companies money in some ways, thus countering the costs of hiring new employees. In the 
present data, it was not possible to calculate exactly how large this effect was, as data on costs of crashes and turnover in this company were not available to us. However, one large bus company in Sweden currently has a total cost of about 70000 SEK for each new bus driver trained (which includes obtaining a bus driver's license), while another company has a mean cost of 10000 SEK for each crash (excluding work costs). Their turnover is 10-20 percent per year. Over a few year's time, the costs and savings could therefore even out, if really bad drivers were replaced by average ones.

What would seem to be apparent is that it cannot simply be assumed that bus driver turnover is a negative occurrence for the companies in this type of business (e.g. Lannoo \& Verhofstadt, 2016). There are also apparent advantages with drivers leaving their profession. However, in the end, it seems like bus companies need to improve upon their selection of drivers (although this is often difficult, because it is hard to find drivers in the first place). Apparently, there are at least three costly variables which are associated here; crashes, absence and turnover. If selection procedures can be constructed which take these parameters into account, strong gains would be possible. Currently, there appears to be no valid tests for any of these factors. It is therefore suggested that research on psychometric tests of the factors of absence and turnover should be undertaken. This can be supplemented with driving tests based on acceleration behaviour (af Wåhlberg, 2007; 2008).

The strength of the present study is the use of company-recorded data, from different sources (in terms of having been created by different sections within the company), as many turnover research studies apparently use single-source surveys (Meyer, Stanley, Hercovitch \& Topolnytsky, 2002). For crash data, self-reports have been shown to be very unreliable (af Wåhlberg, 2011; 2012b; af Wåhlberg \& Dorn, 2015), and it can be suspected that this is the case in the management literature too. Furthermore, the low reliability of self-reported data does not only work as to suppress associations, as assumed by some researchers (e.g. Probst $\&$ Brubaker, 2001), but can actually cause them, a mechanism called common method variance (Cote \& Buckley, 1987; af Wåhlberg, 2009a).

Also, the variables used in the present study are very relevant for industry. Turnover in itself is costly, and if the drivers who leave are also highly crash involved, there is more reason to try to identify these drivers before they are hired (although tests for this cannot be said to have high validity; Van Iddekinge, Roth, Putka \& Lanivich, 2011). Apparently, turnover research has mainly focussed on the costs, and not the benefits, of turnover. We suggest that it would be more prudent to investigate and calculate both sides of this coin.

\section{References}

Arthur, W. Jr., Barrett, G. V., \& Alexander, R. A. (1991). Prediction of vehicular accident involvement: A meta-analysis. Human Performance, 4, 89-105.

Barraclough, P., af Wåhlberg, A. E., Freeman, J., Watson, B., \& Watson, A. (2016). Predicting crashes using traffic offences. A Meta-Analysis that examines potential bias between self-report and archival data. PLoS ONE. http://dx.doi.org/10.1371/journal.pone.0153390

Blom, D. H., Pokorny, M. L., \& van Leeuwen, P. (1987). The role of age and experience in bus drivers' accidents. International Journal of Epidemiology, 16, 35-43.

Boxall, P., Macky, K., \& Rasmussen, E. (2003). Labour turnover and retention in New Zealand: The causes and consequences of leaving and staying with employers. Asia Pacific Journal of Human Resources, 41, 195-214. doi: 10.1177/10384111030412006 
Cantor, D. E., Corsi, T. M., Grimm, C. M., \& Özpolat, K. (2010). A driver focused truck crash prediction model. Transportation Research Part E, 46, 683-692.

Carr, B. R. (1969). A statistical analysis of rural Ontario traffic accidents using induced exposure data. Accident Analysis and Prevention, 5, 343-357.

Chandraratna, S., \& Stamatiadis, N. (2009). Quasi-induced exposure method: Evaluation of not-at-fault assumption. Accident Analysis \& Prevention, 41, 308-313. http://dx.doi.org/10.1016/j.aap.2008.12.005

Cornwall, C. J. (1962). The accident experience of London bus drivers. Annuals of Occupational Hygiene, 5, 69-82. doi:https://doi.org/10.1093/annhyg/5.2.69

Corsi, T. M., \& Fanara, P. (1988). Driver management policies and motor carrier safety. Logistics and Transportation Review, 24, 153-163.

Coruh, E., Bilgic, A., \& Tortum, A. (2015). Accident analysis with aggregated data: The random parameters negative binomial panel count data model. Analytic Methods in Accident Research, 7, 37-49.

Cote, J. A., \& Buckley, R. (1987). Estimating trait, method, and error variance: Generalizing across 70 construct validation studies. Journal of Marketing Research, 24, 315-318. doi: $10.2307 / 3151642$

de Croon, E. M., Sluiter, J. K., Blonk, R. W., Broersen, J.P., \& Frings-Dresen, M. H. (2004). Stressful work, psychological job strain, and turnover: A 2-year prospective cohort study of truck drivers. Journal of Applied Psychology, 89, 442-454.

Cuthbert, J. R. (1994). An extension of the induced exposure method of estimating driver risk. Journal of the Royal Statistical Society, A152, 177-190.

doi: $10.2307 / 2983357$

Dorn, L., \& af Wåhlberg, A. E. (2008). Work related road safety: An analysis based on UK bus driver performance. Risk Analysis: An International Journal, 28, 25-35. doi:10.1111/j.1539-6924.2008.00999.x.

Dorn, L., \& af Wåhlberg, A. E. (submitted, a). A replication study of coding for culpability in traffic accidents.

Dorn, L., \& af Wåhlberg, A. E. (submitted, b). Accident proneness of bus drivers; controlling for exposure.

Evans, G. W. (1994). Working on the hot seat: Urban bus operators. Accident Analysis and Prevention, 26, 181-193. http://dx.doi.org/10.1016/0001-4575(94)90088-4

Faulk, D., \& Hicks, M. J. (2015). The impact of bus transit on employee turnover: Evidence from quasi-experimental samples. Urban Studies, 1-17. doi: 10.1177/0042098015581571

Field, A. P., \& Gillett, R. (2010). How to do a meta-analysis. British Journal of Mathematical and Statistical Psychology, 63, 665-694. doi: 10.1348/000711010X502733 
Griffeth, R. W., Hom, P. W., \& Gaertner, S. (2000). A meta-analysis of antecedents and correlates of turnover: Update, moderator tests, and research implications for the next millennium. Journal of Management, 26, 463-488. doi: 10.1177/014920630002600305

Haight, F. A. (1973). Induced exposure. Accident Analysis and Prevention, 5, 111-126. http://dx.doi.org/10.1016/0001-4575(73)90019-5

Hancock, J. I., Allen, D. G., Bosco, F.A., McDaniel, K. R., \& Pierce, C. A. (2013). Metaanalytic review of employee turnover as a predictor of firm performance. Journal of Management, 39, 573-603. doi: 10.1177/0149206311424943

Harrison, H. D., \& Pierce, J. (2009). Examining Driver Turnover and Retention in the Trucking Industry. Center for Intermodal Freight Transportation Studies, The University of Memphis, Memphis, Tennessee and Vanderbilt University, Nashville, Tennessee.

Harrison, S., \& Gordon, P. A. (2014). Misconceptions of employee turnover: Evidence-based information for the retail grocery industry. Journal of Business and Economics Research, 12, 145-152.

Häkkinen, S. (1958). Traffic Accidents and Driver Characteristics. Doctoral thesis, Finland's Institute of Technology.

Häkkinen, S. (1979). Traffic accidents and professional driver characteristics: A follow-up study. Accident Analysis and Prevention, 11, 7-18. doi: 10.1016/0001-4575(79)90033-2

Jovanis, P. P., Schofer, J. L., Prevedouros, P., \& Tsunokawa, K. (1991). Analysis of bus transit accidents: Empirical, methodological, and policy issues. Transportation Research Record, 1322, 17-28.

Lannoo, S., \& Verhofstadt, E. (2016). What drives the drivers? Predicting turnover intentions in the Belgian bus and coach industry. Transportation Research Part A, 91, 251-259. http://dx.doi.org/10.1016/j.tra.2016.06.024

Lester, J. (1991). Individual differences in accident liability: Review of the literature (TRRL Research Report 306). Crowthorne: Transport and Road Research Laboratory.

McEvoy, G. M., \& Cascio, W. F. (1987). Do good or poor performers leave? A meta-analysis of the relationship between performance and turnover. Academy of Management Journal, 30, 744-762. doi: $10.2307 / 256158$

Meyer, J. P., Stanley, D. J., Herscovitch, L., \& Topolnytsky, L. (2002). Affective, continuance, and normative commitment to the organization: A meta-analysis of antecedents, correlates, and consequences. Journal of Vocational Behavior, 61, 20-52.

http://dx.doi.org/10.1006/jvbe.2001.1842

Mobley, W. H., Griffeth, R. W., Hand, H. H., \& Meglino, B. M. (1979). Review and conceptual analysis of the employee turnover process. Psychological Bulletin, 86, 493-522. http://dx.doi.org/10.1037/0033-2909.86.3.493 
Peck, R. C. (1993). The identification of multiple accident correlates in high risk drivers with specific emphasis on the role of age, experience and prior traffic violation frequency. Alcohol, Drugs and Driving, 9, 145-166.

Probst, T., H., \& Brubaker, T. L. (2001). The effects of job insecurity on employee safety outcomes: Cross-sectional and longitudinal explorations. Journal of Occupational Health Psychology, 6, 139-159. http://dx.doi.org/10.1037/1076-8998.6.2.139

Rajalin, S. \& Summala, H. (1997). What surviving drivers learn from a fatal accident. Accident Analysis and Prevention, 29, 277-283. doi.org/10.1016/S0001-4575(96)00081-4

Staplin, L., \& Gish, K. W. (2005). Job change rate as a crash predictor for interstate truck drivers. Accident Analysis and Prevention, 37, 1035-1039.

Suzuki, Y. (2007). Truck driver turnover: what rate is good enough? International Journal of Physical Distribution \& Logistics Management, 37, 612 - 630.

Taylor, A. H., \& Dorn, L. (2006). Stress, fatigue, health, and risk of road traffic accidents among professional drivers: The contribution of physical inactivity. Annual Reviews of Public Health, 27, 371-391.

http://www.annualreviews.org/doi/10.1146/annurev.publhealth.27.021405.102117

Tse, J. L., Flin, R., \& Mearns, K. (2006). Bus driver well-being review: 50 years of research. Transportation Research Part F, 9, 89-114. http://dx.doi.org/10.1016/j.trf.2005.10.002

Van Iddekinge, C. H., Roth, P. L., Putka, D. J., \& Lanivich, S. E. (2011). Are you interested? A meta-analysis between vocational interests and employee performance and turnover. Journal of Applied Psychology, 96, 1167-1194.

Visser, E., Pijl, Y. J., Stolk, R. P., Neeleman, J., \& Rosmalen, J. G. (2007). Accident proneness, does it exist? A review and meta-analysis. Accident Analysis and Prevention, 39, 556-564. http://dx.doi.org/10.1016/j.aap.2006.09.012

af Wåhlberg, A. E. (2003). Some methodological deficiencies in studies on traffic accident predictors. Accident Analysis and Prevention, 35, 473-486. http://dx.doi.org/10.1016/S0001$\underline{4575(02) 00025-8}$

af Wåhlberg, A. E. (2005). Differential accident involvement of bus drivers. In L. Dorn (Ed.), Driver Behaviour and Training, Volume II. Proceedings of the Second International Conference on Driver Behaviour and Training (pp. 383-391). Aldershot: Ashgate.

af Wåhlberg, A. E. (2007). Long-term prediction of traffic accident record from bus driver celeration behavior. International Journal of Occupational Safety and Ergonomics, 13, 159171.

af Wåhlberg, A. E. (2008). The relation of non-culpable traffic incidents to bus drivers' celeration behavior. Journal of Safety Research, 39, 41-46. doi: 10.1016/j.jsr.2007.10.009

af Wåhlberg, A. E. (2009a). Driver Behaviour and Accident Research Methodology; Unresolved Problems. Farnham: Ashgate. 
af Wåhlberg, A. E. (2009b). Hourly changes in accident risk for bus drivers. Journal of Risk Research, 12, 187-197. https://doi.org/10.1080/13669870802488891

af Wåhlberg, A. E. (2010). A reporting guide for studies on individual differences in safety. Journal of Safety Research, 41, 381-383. doi: 10.1016/j.jsr.2010.05.004.

af Wåhlberg, A. E. (2011). The accident-exposure association: Self-reported versus recorded collisions. Journal of Safety Research, 42, 143-146.

http://dx.doi.org/10.1016/j.jsr.2011.01.007

af Wåhlberg, A. E. (2012a). Changes in driver celeration behavior over time; do drivers learn from collisions? Transportation Research Part F: Traffic Psychology and Behaviour, 15, 471-479. http://dx.doi.org/10.1016/j.trf.2012.04.002

af Wåhlberg, A. E. (2012b). Memory effects in self-reports of crashes. In L. Dorn (Ed.) Driver Behaviour and Training, Volume V, pp. 283-288. Fifth International Conference on Driver Behaviour and Training. Paris November 29-30, 2011. Farnham: Ashgate.

af Wåhlberg, A. E. (2018). The effect of driver improvement interventions on crash involvement; has it been under-estimated? Transportation Research Part F: Traffic Psychology and Behaviour, 54, 349-356. doi.org/10.1016/j.trf.2018.02.027

af Wåhlberg, A. E., Barraclough, P., \& Freeman, J. (2016). Personality versus traffic accidents; meta-analysis of real and method effects. Transportation Research Part F: Traffic Psychology and Behaviour, 44, 90-104. http://dx.doi.org/10.1016/j.trf.2016.10.009

af Wåhlberg, A. E., \& Dorn, L. (2007). Culpable versus non-culpable traffic accidents; what is wrong with this picture? Journal of Safety Research, 38, 453-459.

http://dx.doi.org/10.1016/j.jsr.2007.01.013

af Wåhlberg, A. E., \& Dorn, L. (2009a). Bus driver accident record; the return of accident proneness. Theoretical Issues in Ergonomics Science, 10, 77-91.

http://dx.doi.org/10.1080/14639220801912597

af Wåhlberg, A. E., \& Dorn, L. (2009b). Absence behavior as traffic crash predictor in bus drivers. Journal of Safety Research, 40, 197-201. http://dx.doi.org/10.1016/j.jsr.2009.03.003

af Wåhlberg, A. E., \& Dorn, L. (2015). How reliable are self-report measures of mileage, violations and crashes? Safety Science, 76, 67-73.

DOI: $10.1016 /$ j.ssci.2015.02.020

af Wåhlberg, A. E. \& Dorn, L. (submitted). Experience as a safety factor in bus driving; methodological considerations. 
Table 1 Descriptive data (mean/standard deviation) for drivers who worked for the company until the end of the measurement period, and those who left for various reasons, on the variables of days employed during the crash canvassing period, experience (years of employment), age (2007-06-30) and gender (percent men).

\begin{tabular}{llllll}
\hline Variable & $\mathrm{N}$ & $\begin{array}{l}\text { Days employed } \\
2006-2008\end{array}$ & $\begin{array}{l}\text { Experience on day of } \\
\text { leaving or 2008-12-31 }\end{array}$ & Age (years) & Gender \\
\hline $\begin{array}{l}\text { Still with company 2008- } \\
\text { 12-31 }\end{array}$ & 3124 & $916 / 327$ & $6.22 / 5.63$ & $42.5 / 9.9$ & $94.9 \%$ \\
\hline Resignation & 955 & $374 / 302$ & $2.78 / 3.22$ & $39.5 / 9.9$ & $92.9 \%$ \\
\hline Retirement & 50 & $664 / 369$ & $18.61 / 11.74$ & $65.6 / 10.4$ & $100 \%$ \\
\hline Dismissal & 588 & $493 / 368$ & $4.32 / 5.29$ & $42.2 / 3.1$ & $92.7 \%$ \\
\hline Other & 219 & $400 / 333$ & $4.19 / 5.18$ & $43.5 / 11.2$ & $90.9 \%$ \\
\hline Transfer to other company & 75 & $416 / 301$ & $3.37 / 4.09$ & $43.7 / 10.1$ & $89.3 \%$ \\
\hline Death & 15 & $773 / 346$ & $7.38 / 5.05$ & $54.8 / 9.8$ & $100 \%$ \\
\hline Promotion & 32 & $699 / 183$ & $5.26 / 1.64$ & $41.5 / 10.1$ & $87.5 \%$ \\
\hline
\end{tabular}




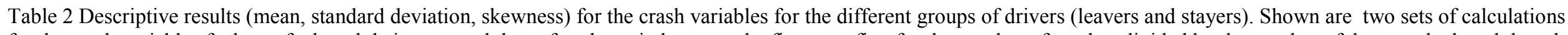

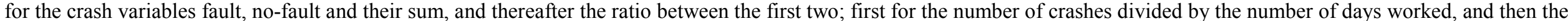

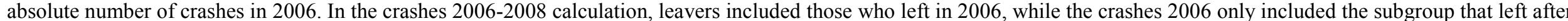
2006.

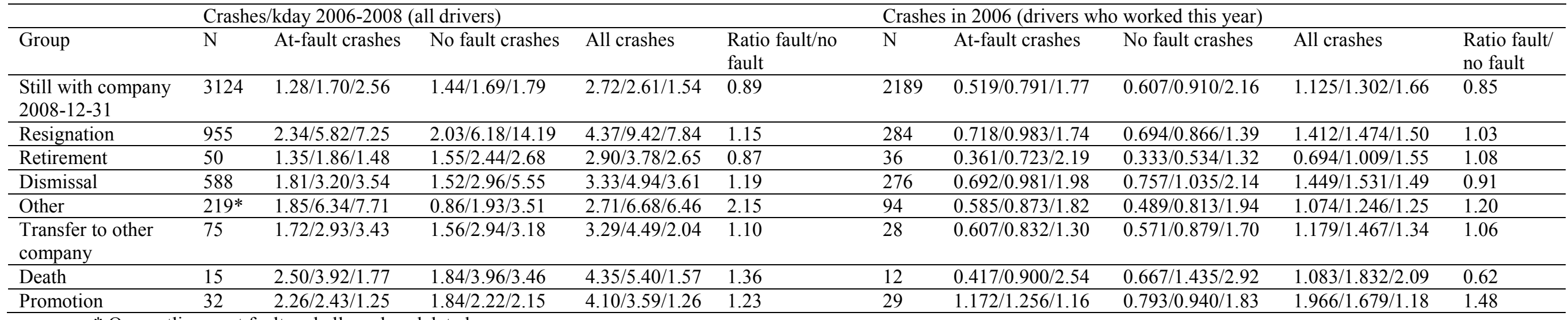

* One outlier on at fault and all crashes deleted. 
Table 3 The effect sizes between groups for accidents/kday 2006-2008 (for the means in Table 2) in the upper right side, and at fault only in the lower left, in terms of independent t-tests (upper value) and Cohen's d (lower value). $\mathrm{N}$ for each group as in Table 2.

\begin{tabular}{|c|c|c|c|c|c|c|c|c|}
\hline Variable & $\begin{array}{l}\text { Still with } \\
\text { company } \\
2008-12- \\
31\end{array}$ & Resignation & Retirement & Dismissal & Other & $\begin{array}{l}\text { Transfer } \\
\text { to other } \\
\text { company }\end{array}$ & Death & Promotion \\
\hline $\begin{array}{l}\text { Still with } \\
\text { company } \\
2008-12-31\end{array}$ & - & $\begin{array}{l}8.75^{* * * *} \\
0.27\end{array}$ & $\begin{array}{l}0.48 \\
0.06\end{array}$ & $\begin{array}{l}4.40^{* * *} \\
0.16\end{array}$ & $\begin{array}{l}0.05 \\
0.00\end{array}$ & $\begin{array}{l}1.80 \\
0.16\end{array}$ & $\begin{array}{l}2.38^{*} \\
0.41\end{array}$ & $\begin{array}{l}2.96^{* *} \\
0.45\end{array}$ \\
\hline Resignation & $\begin{array}{l}9.04 * * * \\
0.28\end{array}$ & - & $\begin{array}{l}1.10 \\
0.22 \\
\end{array}$ & $\begin{array}{l}2.47 * \\
0.14\end{array}$ & $\begin{array}{l}2.47 * \\
0.21\end{array}$ & $\begin{array}{l}0.99 \\
0.16\end{array}$ & $\begin{array}{l}0.01 \\
0.00\end{array}$ & $\begin{array}{l}0.16 \\
0.04\end{array}$ \\
\hline Retirement & $\begin{array}{l}0.30 \\
0.04 \\
\end{array}$ & $\begin{array}{l}1.20 \\
0.26 \\
\end{array}$ & - & $\begin{array}{l}0.60 \\
0.10\end{array}$ & $\begin{array}{l}0.19 \\
0.04\end{array}$ & $\begin{array}{l}0.50 \\
0.09 \\
\end{array}$ & $\begin{array}{l}1.17 \\
0.32 \\
\end{array}$ & $\begin{array}{l}1.43 \\
0.33 \\
\end{array}$ \\
\hline Dismissal & $\begin{array}{l}5.91 * * * \\
0.22\end{array}$ & $\begin{array}{l}2.02 * \\
0.12\end{array}$ & $\begin{array}{l}1.00 \\
0.18\end{array}$ & - & $\begin{array}{l}1.44 \\
0.11\end{array}$ & $\begin{array}{l}0.08 \\
0.01\end{array}$ & $\begin{array}{l}0.78 \\
0.20\end{array}$ & $\begin{array}{l}0.86 \\
0.17\end{array}$ \\
\hline Other & $\begin{array}{l}3.57 * * * \\
0.14\end{array}$ & $\begin{array}{l}1.10 \\
0.08\end{array}$ & $\begin{array}{l}0.55 \\
0.12\end{array}$ & $\begin{array}{l}0.12 \\
0.01\end{array}$ & - & $\begin{array}{l}0.69 \\
0.10\end{array}$ & $\begin{array}{l}0.93 \\
0.27\end{array}$ & $\begin{array}{l}1.15 \\
0.27\end{array}$ \\
\hline $\begin{array}{l}\text { Transfer to } \\
\text { other } \\
\text { company }\end{array}$ & $\begin{array}{l}2.19 * * * \\
0.19\end{array}$ & $\begin{array}{l}0.91 \\
0.14\end{array}$ & $\begin{array}{l}0.79 \\
0.15\end{array}$ & $\begin{array}{l}0.23 \\
0.03\end{array}$ & $\begin{array}{l}0.17 \\
0.03\end{array}$ & - & $\begin{array}{l}0.81 \\
0.21\end{array}$ & $\begin{array}{l}0.91 \\
0.20\end{array}$ \\
\hline Death & $\begin{array}{l}2.77 * * * \\
0.43\end{array}$ & $\begin{array}{l}0.11 \\
0.03\end{array}$ & $\begin{array}{l}1.58 \\
0.40\end{array}$ & $\begin{array}{l}0.82 \\
0.19\end{array}$ & $\begin{array}{l}0.39 \\
0.13\end{array}$ & $\begin{array}{l}0.89 \\
0.23 \\
\end{array}$ & - & $\begin{array}{l}0.18 \\
0.05\end{array}$ \\
\hline Promotion & $\begin{array}{l}3.25 * * * \\
0.47\end{array}$ & $\begin{array}{l}0.07 \\
0.02 \\
\end{array}$ & $\begin{array}{l}1.92 \\
0.42 \\
\end{array}$ & $\begin{array}{l}0.79 \\
0.16 \\
\end{array}$ & $\begin{array}{l}0.36 \\
0.09 \\
\end{array}$ & $\begin{array}{l}0.92 \\
0.20 \\
\end{array}$ & $\begin{array}{l}0.26 \\
0.08 \\
\end{array}$ & - \\
\hline
\end{tabular}


Table 4 The effect sizes between groups for all crashes in 2006 in the upper right side, and at fault only in the lower left, in terms of independent t-tests and Cohen's d. Only drivers who worked during the whole year of 2006. $\mathrm{N}$ for each group as in Table 2.

\begin{tabular}{|c|c|c|c|c|c|c|c|c|}
\hline Variable & Still with company $2008-12-31$ & Resignation & Retirement & Dismissal & Other & Transfer to other company & Death & Promotion \\
\hline Still with company $2008-12-31$ & - & $3.44 * * *$ & $1.97 *$ & $3.82 * * *$ & 0.37 & 0.22 & 0.11 & $3.44 * * *$ \\
\hline $\mathrm{N}=2189$ & & 0.21 & 0.37 & 0.23 & 0.04 & 0.04 & 0.03 & 0.56 \\
\hline Resignation & $3.88 * * *$ & - & $2.84 * *$ & 0.29 & $2.00 *$ & 0.80 & 0.75 & 1.90 \\
\hline $\mathrm{N}=284$ & 0.22 & & 0.58 & 0.02 & 0.25 & 0.16 & 0.20 & 0.35 \\
\hline Retirement & 1.19 & $2.11^{*}$ & - & $2.88 * *$ & 1.63 & 1.56 & 0.93 & $3.78 * * *$ \\
\hline $\mathrm{N}=36$ & 0.21 & 0.42 & & 0.59 & 0.34 & 0.39 & 0.27 & 0.95 \\
\hline Dismissal & $3.33 * * *$ & 0.32 & 1.95 & - & $2.14^{*}$ & 0.89 & 0.80 & 1.71 \\
\hline $\mathrm{N}=276$ & 0.20 & 0.03 & 0.39 & & 0.27 & 0.18 & 0.22 & 0.32 \\
\hline Other & 0.80 & 1.17 & 1.37 & 0.94 & - & 0.37 & 0.02 & $3.09 * *$ \\
\hline $\mathrm{N}=94$ & 0.08 & 0.14 & 0.28 & 0.12 & & 0.08 & 0.01 & 0.61 \\
\hline Transfer to other company & 0.59 & 0.58 & 1.26 & 0.44 & 0.12 & - & 0.17 & 1.88 \\
\hline $\mathrm{N}=28$ & 0.11 & 0.12 & 0.32 & 0.09 & 0.03 & & 0.06 & 0.50 \\
\hline Death & 0.44 & 1.04 & 0.22 & 0.95 & 0.63 & 0.65 & - & 1.49 \\
\hline $\mathrm{N}=12$ & 0.12 & 0.32 & 0.07 & 0.29 & 0.19 & 0.22 & & 0.50 \\
\hline Promotion & $4.38 * * *$ & $2.31 *$ & $3.27 * *$ & $2.44^{*}$ & $2.84 * *$ & 2.00 & 1.89 & - \\
\hline $\mathrm{N}=29$ & 0.64 & 0.41 & 0.82 & 0.43 & 0.55 & 0.54 & 0.70 & \\
\hline
\end{tabular}

$* \mathrm{p}<.05, * * \mathrm{p}<.01, * * * \mathrm{p}<.001$ 


\section{Bus drivers who leave}

Table 5 The mean number of crashes per kday, with standard deviations, for drivers staying and leaving, with effects calculated (independent t-tests, Cohen's d and percent). In the crashes 2006-2008 calculation, leavers included those who left in 2006, while the crashes 2006 only included the subgroup that left after 2006. Also shown is the mean/std experience of the groups.

\begin{tabular}{|c|c|c|c|c|c|c|c|}
\hline \multirow[t]{2}{*}{ Accident variable } & \multicolumn{3}{|c|}{ Still with company $2008-12-31$} & \multicolumn{3}{|c|}{ All drivers leaving, except retirement } & \multirow{2}{*}{$\begin{array}{l}\mathrm{t}, \mathrm{d}, \% \\
\text { (crashes) }\end{array}$} \\
\hline & $\mathrm{N}$ & Experience & Crashes & $\mathrm{N}$ & Experience & Crashes & \\
\hline $\begin{array}{l}\text { All crashes/kday } \\
2006-2008\end{array}$ & 3124 & $6.22 / 5.63$ & $2.72 / 2.61$ & 1886 & $3.53 / 4.32$ & $3.81 / 7.71$ & $\begin{array}{l}7.21 * * * \\
0.21,40 \%\end{array}$ \\
\hline $\begin{array}{l}\text { At-fault crashes/kday } \\
2006-2008\end{array}$ & 3124 & $6.22 / 5.63$ & $1.28 / 1.70$ & 1886 & $3.53 / 4.32$ & $2.09 / 5.06$ & $\begin{array}{l}8.28 * * * \\
0.24,63 \%\end{array}$ \\
\hline All crashes 2006 & 2189 & $8.29 / 5.52$ & $1.13 / 1.30$ & 725 & $6.20 / 4.59$ & $1.39 / 1.49$ & $\begin{array}{l}4.57 * * * \\
0.19,23 \%\end{array}$ \\
\hline At-fault crashes 2006 & 2189 & $8.29 / 5.52$ & $0.52 / 0.79$ & 725 & $6.20 / 4.59$ & $0.70 / 0.98$ & $\begin{array}{l}5.02 * * * \\
0.21,35 \%\end{array}$ \\
\hline $\begin{array}{l}\text { All crashes } 2006 \text {, } \\
\text { equal experience }\end{array}$ & 362 & $0.87 / 0.42$ & $1.24 / 1.31$ & 174 & $0.85 / 0.42$ & $1.49 / 1.55$ & $\begin{array}{l}1.93,0.17, \\
22 \%\end{array}$ \\
\hline $\begin{array}{l}\text { At-fault crashes } \\
2006, \text { equal } \\
\text { experience }\end{array}$ & 362 & $0.87 / 0.42$ & $0.60 / 0.84$ & 174 & $0.85 / 0.42$ & $0.76 / 1.08$ & $\begin{array}{l}1.80,0.16, \\
27 \%\end{array}$ \\
\hline
\end{tabular}

$* \mathrm{p}<.05, * * \mathrm{p}<.01, * * * \mathrm{p}<.001$ 


\section{Bus drivers who leave}

Table 6 Multivariate analysis using multiple regression with crashes per kday as dependent variable. Shown are beta values for age, experience, gender and leave status (no leave/leave except retirement), and the multiple R. One outlier deleted, and fifty other cases excluded due to missing data on one or more variables for the 20062008 period.

\begin{tabular}{|c|c|c|c|c|c|c|c|c|c|}
\hline $\begin{array}{l}\text { Dependent } \\
\text { variable }\end{array}$ & $\mathrm{N}$ & Age & Experience & Gender & $\begin{array}{l}\text { Leave } \\
\text { status }\end{array}$ & $\mathrm{R}$ & $\begin{array}{l}\text { Standard } \\
\text { error of } \\
\text { estimate }\end{array}$ & $\mathrm{F}$ & $\begin{array}{l}\text { Durbin- } \\
\text { Watson } \\
\text { d }\end{array}$ \\
\hline $\begin{array}{l}\text { All } \\
\text { crashes/kday } \\
2006-2008\end{array}$ & 5009 & -.020 & $-.040 *$ & .020 & $-.095 *$ & $.114^{*}$ & 5.15 & 16.6 & 1.28 \\
\hline $\begin{array}{l}\text { At-fault } \\
\text { crashes/kday } \\
2006-2008\end{array}$ & 5008 & .023 & $-.060 *$ & $.029 *$ & $.109^{*}$ & $.133^{*}$ & 3.38 & 22.57 & 1.50 \\
\hline $\begin{array}{l}\text { All crashes } \\
2006\end{array}$ & 2913 & $.042 *$ & $-.080^{*}$ & $.040 *$ & $.076^{*}$ & $.122 *$ & 1.35 & 11.0 & 0.58 \\
\hline $\begin{array}{l}\text { At-fault } \\
\text { crashes } 2006\end{array}$ & 2913 & $.111^{*}$ & $-.100 *$ & .023 & $.086^{*}$ & $.149 *$ & 0.84 & 16.6 & 0.33 \\
\hline
\end{tabular}

$* \mathrm{p}<.05$ 


\section{Bus drivers who leave}

Table 7 Multivariate analysis using logistic regression with crash/no crash as dependent variable. Shown are the number of drivers, the percent of driver with crashes in the period 2006-2008, and the odds ratios for age, experience, gender and leave status (no leave/leave except retirement), with days of work held constant (included in null model). Fifty other cases excluded due to missing data on one or more variables for the 2006-2008 period.

\begin{tabular}{|l|l|l|l|l|l|l|l|}
\hline $\begin{array}{l}\text { Dependent } \\
\text { variable }\end{array}$ & $\mathrm{N}$ & $\begin{array}{l}\text { Percent } \\
\text { with } \\
\text { crashes }\end{array}$ & Age & Experience & Gender & $\begin{array}{l}\text { Leave } \\
\text { status }\end{array}$ & $\begin{array}{l}\text { McFadden } \\
\text { R2 }\end{array}$ \\
\hline $\begin{array}{l}\text { All crashes } \\
2006-2008\end{array}$ & 5009 & $70.7 \%$ & 0.997 & $0.959 * * *$ & 1.108 & $0.576^{* * * *}$ & .012 \\
\hline $\begin{array}{l}\text { At-fault } \\
\text { crashes } \\
\text { 2006-2008 }\end{array}$ & 5009 & $52.2 \%$ & 1.010 & $0.962^{* *}$ & 1.243 & $0.557^{* * *}$ & .012 \\
\hline
\end{tabular}

$* * \mathrm{p}<.01, * * * \mathrm{p}<.001$ 


\section{Bus drivers who leave}

Table 8 Comparison of crashes between drivers in their first year and drivers who left that same year, excluding those who retired, and those who were both hired and left.

\begin{tabular}{|l|l|l|l|l|l|}
\hline & New drivers & \multicolumn{2}{l|}{ Drivers who left } & t, d \\
\hline & Mean/std & $\mathrm{N}$ & Mean/std & $\mathrm{N}$ & \\
\hline All crashes/kday 2006 & $4.38 / 6.87$ & 530 & $3.63 / 7.36$ & 435 & $1.62,0.10$ \\
\hline At-fault crashes/kday 2006 & $2.83 / 5.56$ & 530 & $1.99 / 4.91$ & 435 & $2.47^{*}, 0.16$ \\
\hline All crashes/kday 2007 & $3.93 / 6.80$ & 309 & $2.89 / 6.13$ & 570 & $2.31^{*}, 0.16$ \\
\hline At-fault crashes/kday 2007 & $2.19 / 5.05$ & 309 & $1.44 / 3.39$ & 570 & $2.63^{* *}, 0.18$ \\
\hline All crashes/kday 2008 & $2.11 / 3.46$ & 462 & $4.36 / 11.77$ & 359 & $-3.90^{* * *},-0.30$ \\
\hline At-fault crashes/kday 2008 & $1.17 / 2.65$ & 462 & $2.54 / 8.16$ & 359 & $-3.38^{* * *},-0.25$ \\
\hline
\end{tabular}

$* \mathrm{p}<.05, * * \mathrm{p}<.01, * * * \mathrm{p}<.001$ 


\section{Bus drivers who leave}

Figure 1 The distributions of the crash variables from 2006-2008. Shown are the number of drivers with a certain number of crashes per 1000 work days. Forty-six values $>20$ excluded to make it possible to fit the distribution into a readable figure.

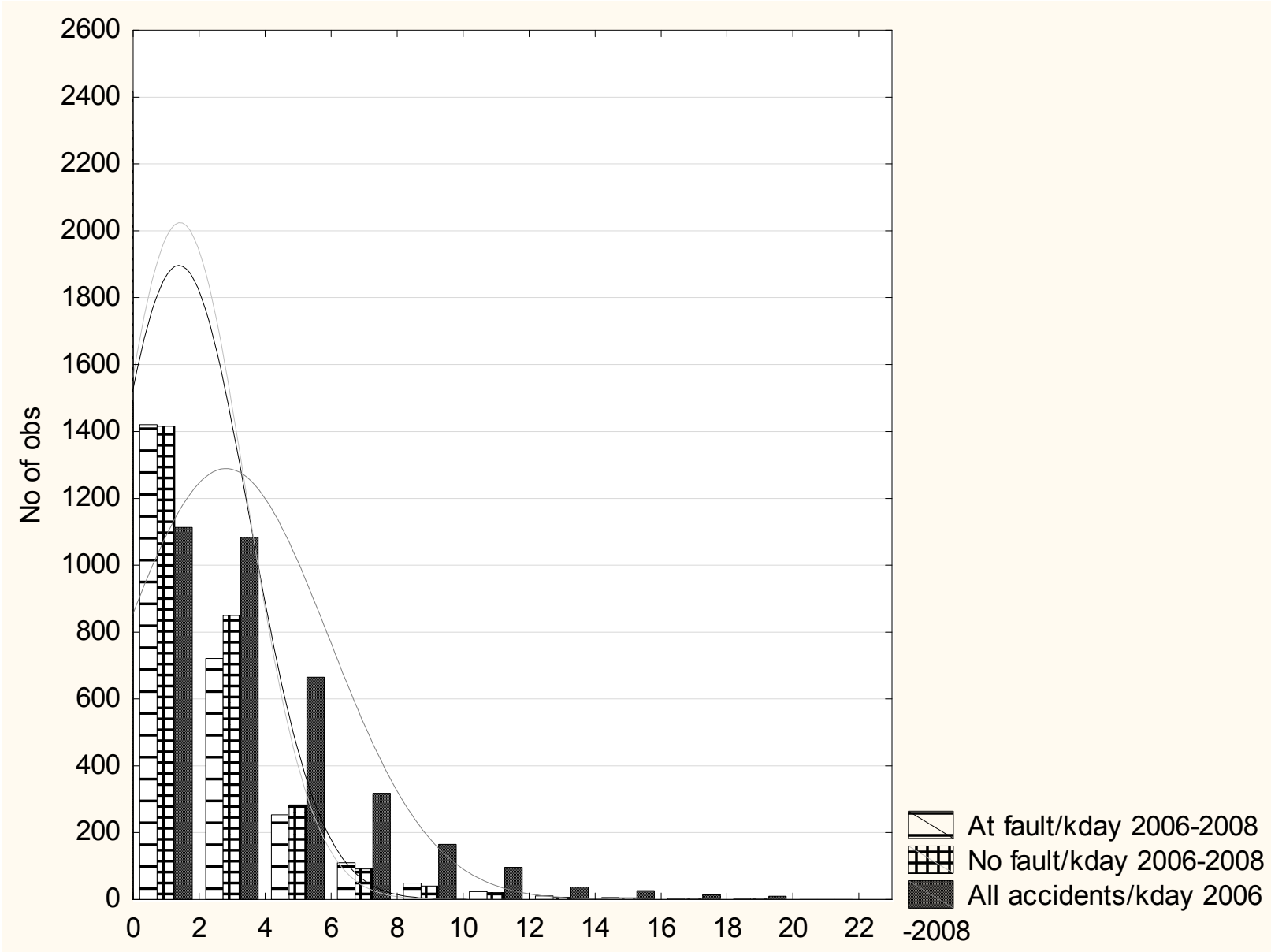




\section{Bus drivers who leave}

Figure 2 The distributions of the three crash variables from 2006. Shown are the number of drivers with a certain number of crashes.

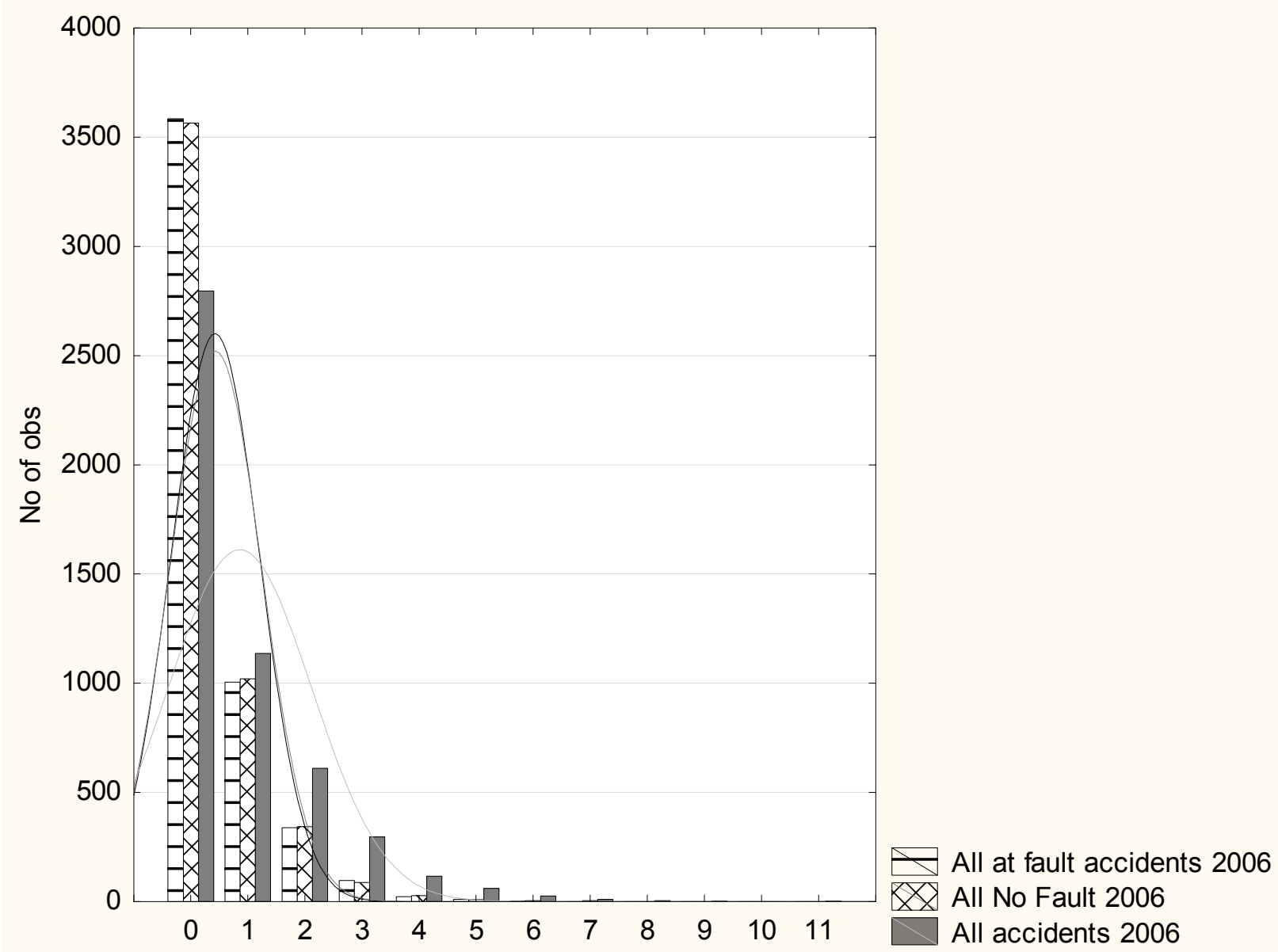




\title{
Cranfield University
}

\section{CERES https://dspace.lib.cranfield.ac.uk}

2018-12-06

Bus drivers who leave: were they more crash-invol

\author{
af Wåhlberg, Anders E.
}

Elsevier

Anders E. af Wåhlberg and Lisa Dorn. Bus drivers who leave: were they more crash-involved?

Transportation Research Part F: Traffic Psychology and Behaviour. Volume 60, January 2019, pp. 524-535

https://doi.org/10.1016/j.trf.2018.11.014

Downloaded from Cranfield Library Services E-Repository 